\title{
PARTIAL REPLACEMENT OF CONCENTRATE BY OF IPOMEA BATATAS LEAVES IMPROVES LITTER SIZE AND SURVIVAL OF YOUNG RABBITS ORYCTOLAGUS CUNICULUS
}

\author{
Otchoumou Kraidy Athanase ${ }^{*} 凹$, Wognin Légbé Marie Flavienne Raïssa ${ }^{1}$, Yao \\ Konan Franck ${ }^{1,2}$, Niamké Sébastien ${ }^{1}$ \\ ${ }^{1}$ Biotechnology Laboratory, Biosciences Faculty, Felix Houphouët Boigny University, 22 BP 582 \\ Abidjan 22 RCI, Côte d'Ivoire \\ ${ }^{2}$ Laboratoire national d'essais de qualité de métrologie et d'analyses, BP V 174 Abidjan RCI, Côte \\ d'Ivoire
}

DOI: https://doi.org/10.29121/granthaalayah.v8.i11.2020.2089

Article Type: Research Article

Article Citation: Otchoumou Kraidy Athanase, Wognin Légbé Marie Flavienne Raïssa, Yao Konan Franck, and Niamké Sébastien. (2020). PARTIAL REPLACEMENT OF CONCENTRATE BY OF IPOMEA BATATAS LEAVES IMPROVES LITTER SIZE AND SURVIVAL OF YOUNG RABBITS ORYCTOLAGUS CUNICULUS. International Journal of Research -GRANTHAALAYAH, 8(11), 1-6. https://doi.org/10.29121/granthaa layah.v8.i11.2020.2089

Received Date: 05 October 2020

Accepted Date: 17 November 2020

\section{Keywords:}

Ipomea Batatas Leaves

Feeding

Rabbit Does

Gestation

Litter Traits

\begin{abstract}
This study was conducted to evaluate the influence of use of Ipomea batatas leaves in the feeding of breeding rabbits. To this end, 28 rabbits does ( $3.2 \mathrm{~kg}$ to $3.5 \mathrm{~kg}$ ), divided into 2 batches (100\% concentrate and $50 \%$ concentrate supplemented with 50\% Ipomea batatas leaves) have been used. The pregnancy rates were $100 \%$ identical. No difference $(\mathrm{P}>0.05)$ was noted between the average feed intake of pregnant rabbits before the farrowing. This parameter was higher in rabbits fed 50\% concentrate supplemented with $50 \%$ Ipomea batatas leaves after births. The mean litter size of the batches fed the mixture feed was (7.66 rabbits / dam) higher ( $\mathrm{P}$ $<0.05$ ) than that of the $100 \%$ concentrate lot (6.85 rabbits / dam). At birth, the mean weight of the rabbits in the $100 \%$ concentrated lot $(48.29 \mathrm{~g})$ was significantly higher $(\mathrm{P}<0.05)$ than that of $50 \%$ concentrate supplemented with $50 \%$ Ipomea batatas leaves (47.74). The rabbits of the $50 \%$ concentrate lot supplemented with Ipomea batatas leaves had a survival rate $(85.71 \%)$ higher than those of the $100 \%$ concentrate batch $(74.50)$ at weaning.
\end{abstract}

\section{INTRODUCTION}

Côte d'Ivoire, like many other developing countries of the world has a protein deficiency gap, especially that of high animal protein. This deficit in animal protein intake has a profound impact on the health status and well-being of the population. The inadequate supply of protein from the traditional livestock (cattle, sheep, goats and poultry) should entail an intensification of the efforts to improve the productivity of the farm animals especially that with

(C) 2020 The Author(s). This is an open access article distributed under the terms of the Creative Commons Attribution License, which permits unrestricted use, distribution, and reproduction in any medium, provided the original author and source are credited. 
short cycle such as the rabbit. The Ivorian rabbit industry has in recent years remarkable development. This development is, however, hampered by a number of factors including the high cost of food which accounts for more than $70 \%$ of the production costs of rabbit farms. As a result, breeders and actors in the national scientific research system are constantly looking for alternative solutions that can contribute to lowering the cost of feed. It is in this context that studies have been undertaken with a view to developing the food resources available locally and accessible at a reduced cost in the rabbits' diet. The studies carried out on the valorization of fodder have given fairly satisfactory results which make it possible today to judge the nutritional interest of some forages (Abelmoschus esculentus, Vigna unguiculata, Corchorus olitorius, Ipomea batatas, Solanum melongena, Leuceana leucocephala, Puerarea phaseoloides) for fattening animals [1], [2], [3]. The results of these trials suggest the possibility of using these forages for the production of feed for breeders. The results of these studies suggest the possibility of using these forages for the production of feed for breeders. As a result, it was considered essential to extend the studies on young rabbits to breeding females. The purpose of this study was to evaluate the effects of potato leaves on reproductive performance (fertility, gestation length, litter size, birth weight of rabbits) on rabbits and on litter survival.

\section{MATERIALS AND METHODS}

\subsection{ANIMALS AND MANAGEMENT}

The experiment was held out in traditional rabbitary farm of Bingerville municipality, located on latitudes $5^{\circ}$ 21'708 "North and longitudes 3० 54'639" west in Côte d'Ivoire. The study included 16 adult rabbits from mating between New Zealand White X California. The rabbits were composed of 7 males ranging in weight from $2.5 \mathrm{~kg}$ to $2.9 \mathrm{~kg}$ and 28 females weighing between 3.2 and $3.5 \mathrm{~kg}$ body weight. They were housed individually and fed in wirenetting $(70 \times 40 \times 50 \mathrm{~cm})$ equipped with aluminum feeders and drinkers. The cages, feeders and drinkers were thoroughly washed and disinfected before rabbits were allocated into them. These animals from the same herd were selected according to their weight and performance. Thus 28 crosses were made and allowed to obtain young rabbits. We proceeded by the selection of male and female breeders. The breeders selected were those who had two births each. The selection criterion of males was at least one year of age.

Two animal bands were formed: one strip with 14 females fed only with $100 \%$ concentrate and the second with 14 females receiving 50\% concentrate and 50\% Ipomea batatas leaves. The males were fed with $100 \%$ concentrate. After 14 feeding days, we proceeded to the male of the female for mating and observed the effectiveness of projections for 1/4 hour. Each male. Once the projections were completed, the female was immediately removed from the male's cage and returned to that of the maternity ward; then we noted the date of the coupling, the number of the female and that of the male. Each male received a total of 4 females consisting of 2 females from each band. Five days later, we proceed to test protests, that is to say, bring the female back into the male's cage and observe for $1 / 4$ hour, if she could accept the male again (negative test). When she was pregnant, we wrote down the likely date of farrowing after mating [4]. After the farrowing, we counted with the help of a stick the little rabbits born. The rabbits from these kiddings were singly weighed with an electronic precision balance1/100 every week until 35 days (weaning age). The young rabbits were stayed with their mother, with a free access to water and feed.

Female's feed intake (FI) was taken as the difference between the feed supplied and left over for each replicate per day. The young rabbits were weighed on weekly basis and weight gain for each animal per week was calculated as the difference between the present weight and the weight for the previous week. The daily weight gain (DWG) was obtained by dividing the total weight gain by the number of days.

\section{RESULTS AND DISCUSSIONS}

\subsection{GESTATION, KINDLING AND BIRTHS}

At the end of the palpation, it was found that $100 \%$ of the females put in experimentation were declared pregnant (Table 1). All the rabbits fed 50\% concentrate and 50\% Ipomea batatas leaves, gave birth. This suggests that Ipomea batatas leaves would not contain any substance that can directly or indirectly reduce the effectiveness 
of embryo growth hormones as has been demonstrated with nem leaves. Indeed Suryawanshi [5] reports that the chemical constituents of neem stimulate the immune system of pregnant females to reduce the effectiveness of growth hormones of embryos at the blastocyst stage. However, these hormones intervene in cell differentiation and survival, especially during embryogenesis [6] by stimulating cell mitosis. This blockage of embryonic epithelial growth factor activity during the first week of management causes degeneration of embryos at the blastocyst stage [5], [7], [8]. All lots combined; the earliest farrowing took place on the 31th day of pregnancy against 33 days for the longest gestations. Toleba et al. [9] reported gestational time ranging from 31 to 34 days in rabbits fed forage. Defan et al. [10] also noted an average gestation time of 31 days in rabbits fed different forages complemented to concentrate. While in this study, the mean duration of gestation recorded in the batch fed with concentrate combined with Ipomea batatas leaves $(32,28 \pm 0,72$ day) was longer than that of the females in the control lot $(31,71 \pm 0,72$ day) $(\mathrm{P}<0,05)$. No cases of aborted fetuses were found during the study. Females in the control lot had a higher farrowing rate at day 31(21.42\%) ( $\mathrm{P}<0.05)$ than females fed 50\% concentrate and 50\% Ipomea batatas leaves $(7.14 \%)$. Chrysostome et al. [11] noted that local rabbits had an average gestation duration of 31.8 days. The results obtained in the batches of this experiment are in agreement with the results obtained by these authors on the females of local breeds. At day 32, the farrowing rate is similar for all the batches $(21.42 \%)$, which is not the case for the 33rd day because this parameter is higher in females stuck with pellet and potato leaves $(21.42 \%$ vs $7.14 \%)(p<0.05)$.

\subsection{LITTER PERFORMANCES}

Figure 1 shows the growth curve of young rabbits from birth to weaning. This evolution is regular throughout the growth period for all treatments. However, it shows two phases during which the evolution of the live weight according to the diet is different. Indeed, between the birth and the 7th day, the growth between the lots is simular. Beyond this, the live weight of the rabbits in the batch where the mother receives $100 \%$ concentrate throughout the reproductive cycle remains higher than the other batch (Figure 1).

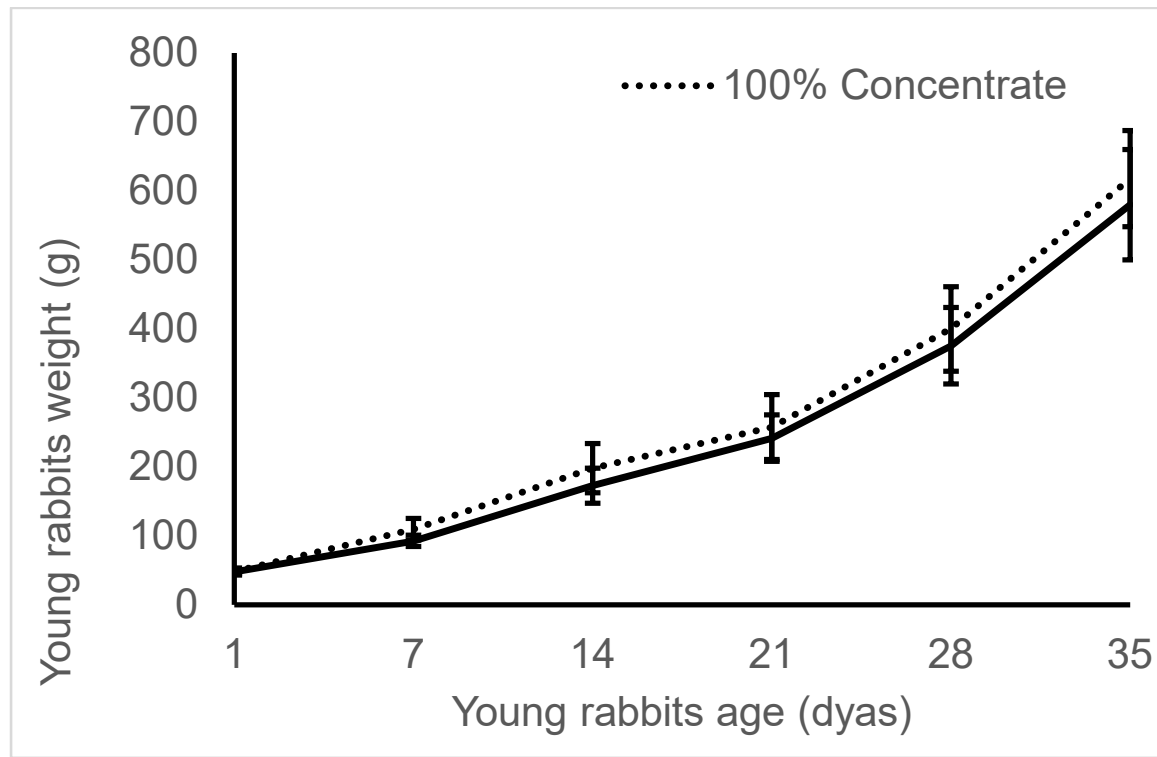

Figure 1: Evolution of young rabbits fed with different types of feed

The average litter size at birth, at weaning of batch of 50\% concentrate and 50\% Ipomea batatas leaves $(7.66 \pm$ 0.81 and $7.00 \pm 1.87$ respectively) was higher than that recorded in the other batch of $100 \%$ concentrate (6.85 \pm 0.89 and $6.33 \pm 1.21$ ) but the weight of their litter was highest $(48.29 \pm 5.13 \mathrm{~g}$ vs $47.74 \pm 2.41 \mathrm{~g}$ and $617,37 \pm 70.17 \mathrm{~g}$ vs 580 $\pm 23.51 \mathrm{~g})(\mathrm{P}<0.05)$ (Table 1$)$.

The litter size in this study compares favourably with the litter size range of $6.75-7.75$ and $6.72-7.75$ respectively at birth and at weaning reported by Ironkwe and Ukanwoko [12] but higher than the litter sizes of 4.24 and $5.00-6.25$ reported by Iheukwumere [13]-. This result indicates the Ipomea batatas leaves favors the number litter in breeding females (Table 1). While the values of litter weight at birth and at weaning were inferior to those reported by Defan et al. [10]- with concentrate plus L. hexandre (48.76 g and $218 \mathrm{~g}$ ) and concentrate associated to $P$ 
maximum ( $49.60 \mathrm{~g}$ and $305 \mathrm{~g}$ ) for the litter weight at birth. This difference can be attribued to forage used. However, the litter weight at weaning was higher than those reported by Defan et al. [10] whatever the forage used.

Table 1: Reproductive performance of rabbit does and litters traits

\begin{tabular}{|c|c|c|}
\hline Parameters & \multicolumn{2}{|c|}{ Treatments } \\
\cline { 2 - 3 } & $\begin{array}{c}100 \% \\
\text { concentrate }\end{array}$ & $\begin{array}{c}\text { 50\% concentrate+ 50\% Ipomea batatas } \\
\text { leaves }\end{array}$ \\
\hline Kindling (\%) & 100 & 100 \\
\hline Farrowing rate at 31 day (\%) & 21.42 & 21.42 \\
\hline Farrowing rate at 32 day (\%) & 21.42 & 21.42 \\
\hline Farrowing rate at 33 day (\%) & 7.14 & $32.28 \pm 0.72^{\mathrm{b}}$ \\
\hline Gestation length & $31.71 \pm 0.72^{\mathrm{a}}$ & $4.66 \pm 0.81^{\mathrm{b}}$ \\
\hline Average litter size at the birth & $6.85 \pm 0.89^{\mathrm{a}}$ & $7.74 \pm 2.41^{\mathrm{a}}$ \\
\hline Average young rabbit weight at birth (g) & $48.29 \pm 5.13^{\mathrm{b}}$ & $8.00 \pm 1.87^{\mathrm{b}}$ \\
\hline Average litter size at weaning & $6.33 \pm 1.21^{\mathrm{a}}$ & $6.12^{\mathrm{a}}$ \\
\hline Survival rate at weaning (\%) & $74.50 \pm 2.89^{\mathrm{a}}$ & $0.07^{\mathrm{a}}$ \\
\hline Death rate from 0 to 7 day (\%) & $7.84^{\mathrm{b}}$ & $4.44^{\mathrm{b}}$ \\
\hline Death rate from 7 to 14 day (\%) & $4.25^{\mathrm{b}}$ & 0.00 \\
\hline Death rate from 14 to 21 day (\%) & $4.44^{\mathrm{b}}$ & $580 \pm 23.51^{\mathrm{a}}$ \\
\hline Death rate from 21 to 28 day (\%) & $2.32^{\mathrm{a}}$ & \\
\hline Death rate from 28 to 35 (weaning) day & 0.00 & \\
\hline Average young rabbit weight at weaning & $617.37 \pm 70.17^{\mathrm{b}}$ & \\
\hline (g) & & \\
\hline
\end{tabular}

Values in the same column with different superscripts were significantly different $(\mathrm{P}<0.05)$

\subsection{THE SURVIVAL OF YOUNG RABBITS}

Mortality is highest in the control lot ( $100 \%$ concentrate) from birth to weaning. The majority of the deceased in the control group had first bloated belly before dying. In addition to breastmilk, rabbits also benefited from food served to their mothers. Thus, those who had the leaves at their disposal could see their digestive transit facilitated, which could surely lead to high survival. The mortality can be attributed to as trampling in certain cases.

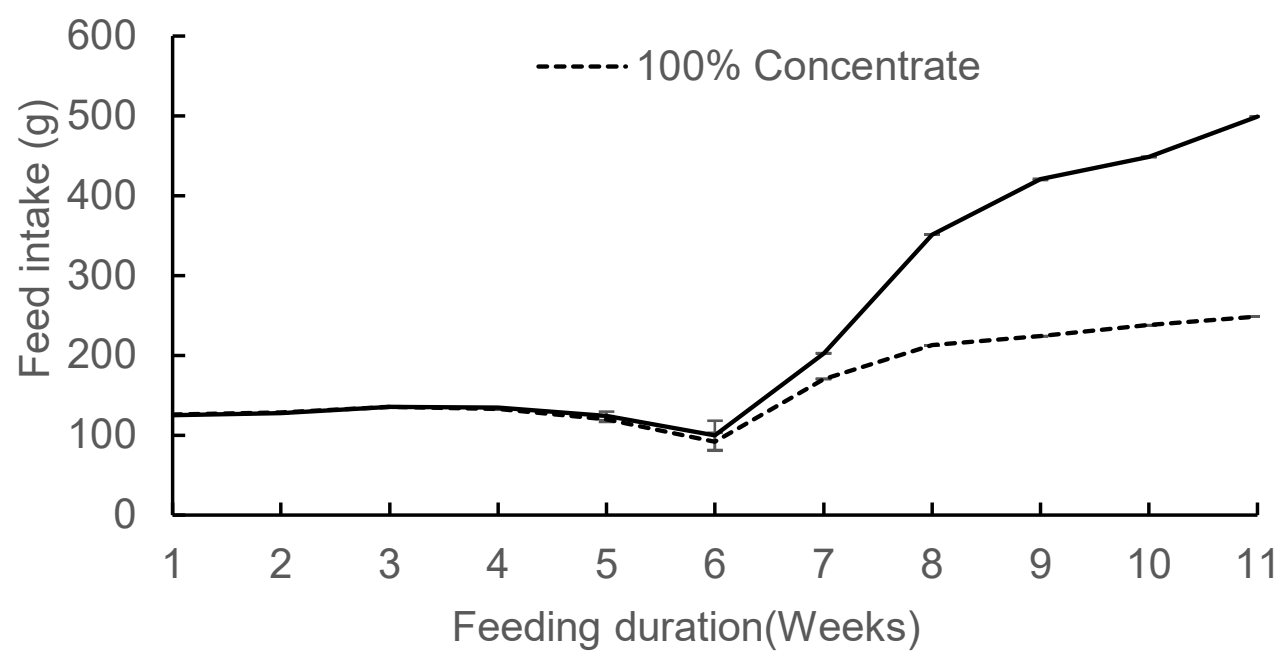

Figure 2: Evolution of feeding intake of rabbit does 


\subsection{FEMALES FEED INTAKE}

No significant difference ( $\mathrm{P}>0.05$ ) was observed for feed consumption during gestation period (Figure 3 ). The increase of feed intake from the beginning of gestation to the 21st day in females must be attributed to their physiological state. Indeed, in addition to their individual need, females must also meet the nutritional needs of their fetuses. For this purpose, Fortun-Lamothe and Lebas [14] mention that, in order to meet the higher energy requirements related to the maintenance energy needs of fetuses, rabbits increase their diet consumption during pregnancy. The decreased of feed intake observed during gestation (21st and 28th day of gestation) coincides with the period of preparation of the nest box by females. During this period, when rabbits are busy peeling and wrapping the nest box with hairs, the amount of time spent feeding is thus reduced. During lactation, feed intake was significantly $(\mathrm{P}<0.05)$ higher for rabbits fed diet containing concentrate and Ipomea batatas (Figure 3$)$. This observation was made by Defang et al. [10] in the rabbits fed diet containing concentrate and forage combination. The difference in feed intake could be attributed to difference in the energy quantity of diet. Indeed, during the lactation, the energy requirement of rabbit increases and to compensate for the deficit due to the leaf combination, the rabbits must ingest more feed.

\section{CONCLUSIONS AND RECOMMENDATIONS}

The study of the incorporation of Ipomea batatas leaves into the diet of rabbits revealed an improvement in their performance. Indeed, the association of Ipomea batatas leaves in the feed has allowed an increase in the number of litters, to reduce the morbidity and the mortality of the rabbits, to have an average weight of the rabbits at the birth and the weaning of acceptable. It would also be important to know the influence of Ipomea batatas leaves on dairy production in rabbits.

\section{SOURCES OF FUNDING}

This research received no specific grant from any funding agency in the public, commercial, or not-for-profit sectors.

\section{CONFLICT OF INTEREST}

The author have declared that no competing interests exist.

\section{ACKNOWLEDGMENT}

None.

\section{REFERENCES}

[1] Kimse, M., Soro, D., Bléyéré, M. N., Yapi, J. N., \& Fantodji A. (2013). Apport d’un fourrage vert tropical, Centrosoma pubescens, en complément au granulé : effet sur les performances de croissance et sanitaire du lapin (Oryctolagus cuniculus). Internatinal Journal of Biological and Chemical Sciences, 7 (3): 1234-1242.

[2] Yao, K. F., Otchoumou, K. A., Wognin, L. R. M. F., Konan, K. A., \& Niamké, S. (2016): Growth Parameters, Protein Digestibility and Health Status of Rabbit Oryctolagus Cuniculus Fed with Palatable Leafy Vegetables. European Scientific Journal, 12 (27): 191-207.

[3] Wognin, L. R. M. F, Otchoumou, K. A., Yao, K. F., \& Niamké, S. (2018). Improving the nutritive value and sensory quality of rabbit meat by using leafy vegetables as feedstuffs; Journal of Animal \& Plant Sciences. 36 (1): 5812 5824

[4] Museba, W.; Kashala, K.; Mutondo, L.; Lunumbi, O., \& Kumwimba, L (2016) Contribution a l'étude des effets de croisement sur la taille de la portée et la croissance des lapereaux : Cas de la ferme agro- pastorale Jacarandas en R.D.Congo. Journal of Applied Biosciences 104:9921 - 9931 
[5] Suryawanshi, A. J. S. (2011). Neem-natural contraceptive for male and female - an overview. International Journal of Biomolecules and Biomedicine, 1 (2): 1-6

[6] Barritault, M. M., \& Loret C. (1982). Nature et propriétés de divers facteurs de croissance. médecine/sciences. 1: 80-85.

[7] Bhowmik, D., Chiranjib, Yadav J., Tripathi, K. K., \& Kumar, K. K. S. (2010). Herbal remedies of Azadirachta indica and its MedicinalApplication. Journal of Chemical and Pharmaceutical Research. 1:62-72.

[8] Delesalle, V. F. C. (2016). Ethno-pharmacognosie vétérinaire en élevage avicole, bovin, bubalin et porcin au Cambodge. Thèse pour l'obtention du doctorat vétérinaire. Ecole nationale vétérinaire d'Alfort, France. 321 p.

[9] Toleba, S. S, Dahouda, M., Vidjannagni, D. S., Sina H., Natonnagnon U., Harouna A., Adeline A.D., Anagonou N. S. I., and Moussa, L. B (2017). Ingestions alimentaires et performances de production et de reproduction des lapines (oryctolagus cuniculus) gestantes nourries avec des aliments contenant des feuilles de Neem (Azadirachta Indica). European Scientific Journal 13 (15) : 82-100

[10] Defang, H. F, Kana, J. R., Ngoula, F., Keambou, T. C, Teguia A., \& Emene, N. (2013) reproductive performance of local rabbit does on sweet Potato concentrate meal to forage combinations under Tropical condition.; Wayamba Journal of Animal Science 647-653

[11] Chrysostome, C. A. A. M., Houndonougbo, M. F., Gbangboché, A.B., \& Houangni, M. S. M. (2011). Evaluation of reproduction performance of Hyla rabbits in hot and humid region in Benin. Research Opinion Animal Veterinary Sciences, 1(10): 669-672

[12] Ironkwe, O. M., \& Ukanwoko, I. A. (2016). The Evaluation of Concentrate and Forage Combination on the Performance and Litter Weight of New Zealand Rabbit. Greener Journal of Agricultural Sciences 6 (10): 312315.

[13] Iheukwumere, F. C. (2008). Effect of mixed feeding regime on litter performance traits of rabbit does. Pakistan Journal of Nutrition 7(4): $594-596$.

[14] Fortun-Lamothe, L., \& Lebas, F. (1998). Effects of simultaneous pregnancy and lactation in primiparous rabbit does on weight and composition of new born rabbits. In: Rabbit production in hot climates (p. 10). Presented at 2. International conference, Adana, TUR (1998-09-07 - 1998-09-08). http://prodinra.inra.fr/record/137535. 